\title{
Operário em (des)construção
}

Adilson Citelli*

Professor titular do Departamento de Comunicações e Artes da ECA/USP, onde ministra cursos de graduação e pós-graduação. Orienta dissertações e teses nas áreas de Comunicação e Linguagem, com ênfase nas subáreas Comunicação/Educação, Comunicação/Linguagem. É coeditor da revista Comunicação \& Educação, bem como pesquisador $1 \mathrm{C}$ do $\mathrm{CNPq}{ }^{* * *}$.

E-mail: citelli@uol.com.br

Nesta edição, a revista Comunicação \& Educação publica dois textos que explicitam uma série de contradições que matizam o modo de produção capitalista, destacando, sobretudo, o problema da reificação, da apropriação alienada do trabalho. Sob andamentos um pouco diferentes, o tema do assujeitamento, da subsunção da vida humana aos interesses do capital, é elaborado em duas obras que já se tornaram clássicas: $O$ operário em construção, poema de Vinicius de Moraes, publicado em 1956, na primeira edição do quinzenário Para Todos, e a canção de Chico Buarque, Construção, lançada em 1971, em LP de mesmo nome. Os dois textos relatam a trajetória de operários que laboram na construção civil e se acham marcados pelas duras condições que acompanham suas atividades. Entretanto, como se verá, os textos revelam singularidades no modo de tratar o assunto; enquanto um indica falta de saída, criando um sufocante clima de impossibilidades, o outro aponta alternativas, mostrando um possível caminho para o trabalhador superar as condições que o degradam.

Na canção de Chico Buarque, o elemento dramático se faz presente no primeiro verso: "Amou daquela vez como se fosse a última", passagem que prenuncia a tragédia final do trabalhador. Na sequência das estrofes constituem-se os lineamentos desumanizadores do sujeito ante as coisas e as funções por ele exercidas: "Subiu a construção como se fosse máquina", "Seus olhos embotados de cimento e lágrima": fusão coisificadora de elementos espirituais e materiais; movimento que promove a alegoria da perda dos sentidos que deveriam singularizar o ser humano. Tudo isto evidencia a condição de não sujeito do trabalhador. Diante da opressão e da falta de saída no interior de um sistema que afirma a matéria em detrimento da subjetividade, da afetividade, dos elementos de identidade, ao operário só cabe o final trágico e desumanizador: "E se acabou no chão feito um pacote flácido".

O poema de Vinicius de Moraes aborda, inicialmente, a contradição do sistema capitalista ao descrever a trajetória do trabalhador: "Sendo sua liberdade / Era a sua escravidão”. Em meio ao processo de alienação, o personagem do

\footnotetext{
* Com a colaboração de Cristine Vargas (revista Comunicação \& Educação - ECA/USP e FFLCH/ USP).

** É autor de inúmeros artigos e livros, dentre os quais se destacam: Linguagem e persuasão (Ática: 1994); Comunicação e educação: a linguagem em movimento (Senac: 2000); Palavras, meios de comunicação e educação (Cortez: 2006).
} 
comunicação \& educação • Ano XV • número 2 • maio/ago 2010

texto passa por um processo de conscientização ao perceber que "Tudo naquela mesa / Garrafa, prato, facão / Era ele quem fazia / Ele um humilde operário / Um operário em construção". Ao ganho de consciência, sucede a resistência ao sistema: "E foi assim que o operário / Do edifício em construção / Que sempre dizia sim / Começou a dizer não". Por fim, a redenção é apresentada através da possibilidade de o sujeito reinterpretar o universo que o circunda, adentrando um novo plano existencial: "O operário adquiriu / Uma nova dimensão: / A dimensão da poesia”.

\section{REFERÊNCIAS BIOGRÁFICAS}

\section{Chico Buarque}

No dia 19 de junho de 1944, nasce, no Rio de Janeiro, Francisco Buarque de Hollanda, o quarto dos sete filhos do historiador e sociólogo Sérgio Buarque de Hollanda e da pianista amadora Maria Amélia Cesário Alvim. Em São Paulo, o compositor fez o Ensino Fundamental e Médio no Colégio Santa Cruz, onde se apresentou pela primeira vez num palco com uma composição própria, Canção dos olhos.

Em 1963, ingressa na Faculdade de Arquitetura e Urbanismo da USP, cursando apenas até o terceiro ano. No ano seguinte, inscreve-se no festival promovido pela TV Excelsior com a canção Sonho de um Carnaval, cantada por Geraldo Vandré. Em 1965, lança sua primeira gravação, o compacto Olé Olá. Sua projeção nacional ocorreria logo depois, ao vencer o festival de MPB da TV Record, com a canção $A$ banda.

Em 1967, Chico Buarque estreia a peça Roda-viva, entretanto, com o acirramento da ditadura militar, o espetáculo é censurado. Em 1968, Chico exila-se na Itália. Voltando ao Brasil em 1970; produz, no ano seguinte, o álbum Construção.

Em 1974, lança o álbum Sinal Fechado e inicia a carreira de escritor ao publicar a novela Fazenda modelo. Um ano depois, escreve com o dramaturgo Paulo Pontes a peça Gota d'água. Segue-se a Ópera do malandro, obra na qual Chico Buarque escreve e compõe as canções, e que resulta no Prêmio Molière de melhor autor teatral de 1978. Em 1979, publica o livro infantil O chapeuzinho amarelo.

A partir de 1992 publica uma série de romances: Estorvo, com o qual ganha o Prêmio Jabuti de Literatura; Benjamin (1995); Budapeste (2003); e O leite derramado (2009).

\section{Vinicius de Moraes}

Marcus Vinitius da Cruz e Mello Moraes nasce em 19 de outubro de 1913, no bairro da Gávea, no Rio de Janeiro, filho da pianista Lydia Cruz de Moraes e do poeta bissexto Clodoaldo Pereira da Silva Moraes. Escreve seu primeiro 
poema aos sete anos de idade. Aos nove, vai com a irmã Lygia a um cartório e altera seu nome para Vinicius de Moraes.

Aos 19 anos publica seu primeiro livro de poesia, Caminho para a distância, e aos 22, ganha o Prêmio Felipe d'Oliveira pelo livro Forma e exegese, publicado em 1935. Cursa a faculdade de Direito no Rio de Janeiro e Literatura Inglesa na Universidade de Oxford, Inglaterra.

Ingressa na carreira diplomática, por concurso, em 1943, tendo servido em Los Angeles, Paris e Montevidéu. Vinicius de Moraes foi ainda crítico e censor cinematográfico. Como delegado brasileiro, participou de festivais internacionais de cinema em Cannes, Berlim, Locarno, Veneza e Punta del Leste. Em 1966, fez parte do Júri Internacional de Cannes. Seu drama Orfeu da Conceição foi montado para o teatro em 1953 e transposto para o cinema por Marcel Camus, em 1959; com Orfeu negro, ganha a Palma de Ouro do Festival de Cannes e o Oscar de Hollywood como o melhor filme estrangeiro.

$\mathrm{Na}$ década de 1960, integra o movimento musical conhecido como Bossa Nova, mesclando elementos de samba e jazz. Faz parceria com Pixinguinha, Carlos Lyra, Ary Barroso, João Gilberto, Francis Hime, Edu Lobo, Baden Powell, Toquinho e Tom Jobim, com quem comporia a música Garota de Ipanema. Diversos poemas seus foram posteriormente musicados.

Em 1969, é exonerado do Itamaraty. Ao confirmar os boatos de que o governo o perseguia, viaja pela Europa e grava dois discos na Itália com Toquinho, em 1975.

No dia 17 de abril de 1980, é operado, no Rio de Janeiro, para a instalação de um dreno cerebral e, na manhã de 9 de julho, falece de edema pulmonar, em sua casa na Gávea, em companhia de sua última mulher e do parceiro musical Toquinho.

\section{POESIAS}

\section{Construção}

Amou daquela vez como se fosse a última

Beijou sua mulher como se fosse a última

E cada filho seu como se fosse o único

E atravessou a rua com seu passo tímido

Subiu a construção como se fosse máquina

Ergueu no patamar quatro paredes sólidas

Tijolo com tijolo num desenho mágico

Seus olhos embotados de cimento e lágrima

Sentou pra descansar como se fosse sábado

Comeu feijão com arroz como se fosse um príncipe

Bebeu e soluçou como se fosse um náufrago

Dançou e gargalhou como se ouvisse música 
comunicação \& educação • Ano XV • número 2 • maio/ago 2010

E tropeçou no céu como se fosse um bêbado

E flutuou no ar como se fosse um pássaro

E se acabou no chão feito um pacote flácido

Agonizou no meio do passeio público

Morreu na contramão atrapalhando o tráfego

Amou daquela vez como se fosse o último

Beijou sua mulher como se fosse a única

E cada filho seu como se fosse o pródigo

$\mathrm{E}$ atravessou a rua com seu passo bêbado

Subiu a construção como se fosse sólido

Ergueu no patamar quatro paredes mágicas

Tijolo com tijolo num desenho lógico

Seus olhos embotados de cimento e tráfego

Sentou pra descansar como se fosse um príncipe

Comeu feijão com arroz como se fosse máquina

Dançou e gargalhou como se fosse o próximo

E tropeçou no céu como se ouvisse música

E flutuou no ar como se fosse sábado

E se acabou no chão feito um pacote tímido

Agonizou no meio do passeio náufrago

Morreu na contramão atrapalhando o público

Amou daquela vez como se fosse máquina

Beijou sua mulher como se fosse lógico

Ergueu no patamar quatro paredes flácidas

Sentou pra descansar como se fosse um pássaro

E flutuou no ar como se fosse um príncipe

E se acabou no chão feito um pacote bêbado

Morreu na contramão atrapalhando o sábado.

\section{O operário em construção}

E o Diabo, levando-o a um alto monte, mostrou-lhe num momento de tempo todos os reinos do mundo. E disse-lhe o Diabo:

- Dar-te-ei todo este poder e a sua glória, porque a mim me foi entregue e dou-o a quem quero; portanto, se tu me adorares, tudo será teu.

E Jesus, respondendo, disse-lhe:

- Vai-te, Satanás; porque está escrito: adorarás o Senhor teu Deus

e só a Ele servirás.

Lucas, cap. V, vv. 5-8.

Era ele que erguia casas

Onde antes só havia chão.

Como um pássaro sem asas

Ele subia com as casas 


\section{O operário em (des)construção • Adilson Citelli}

Que lhe brotavam da mão.

Mas tudo desconhecia

De sua grande missão:

Não sabia, por exemplo

Que a casa de um homem é um templo

Um templo sem religião

Como tampouco sabia

Que a casa que ele fazia

Sendo a sua liberdade

Era a sua escravidão.

De fato, como podia

Um operário em construção

Compreender por que um tijolo

Valia mais do que um pão?

Tijolos ele empilhava

Com pá, cimento e esquadria

Quanto ao pão, ele o comia...

Mas fosse comer tijolo!

E assim o operário ia

Com suor e com cimento

Erguendo uma casa aqui

Adiante um apartamento

Além uma igreja, à frente

Um quartel e uma prisão:

Prisão de que sofreria

Não fosse, eventualmente

Um operário em construção.

Mas ele desconhecia

Esse fato extraordinário:

Que o operário faz a coisa

E a coisa faz o operário.

De forma que, certo dia

À mesa, ao cortar o pão

O operário foi tomado

De uma súbita emoção

Ao constatar assombrado

Que tudo naquela mesa

- Garrafa, prato, facão -

Era ele quem os fazia

Ele, um humilde operário

Um operário em construção

Olhou em torno: gamela 
Banco, enxerga, caldeirão

Vidro, parede, janela

Casa, cidade, nação!

Tudo, tudo o que existia

Era ele quem o fazia

Ele, um humilde operário

Um operário que sabia

Exercer a profissão.

Ah, homens de pensamento

Não sabereis nunca o quanto

Aquele humilde operário

Soube naquele momento!

Naquela casa vazia

Que ele mesmo levantara

Um mundo novo nascia

De que sequer suspeitava.

O operário emocionado

Olhou sua própria mão

Sua rude mão de operário

De operário em construção

E olhando bem para ela

Teve um segundo a impressão

De que não havia no mundo

Coisa que fosse mais bela.

Foi dentro da compreensão

Desse instante solitário

Que, tal sua construção

Cresceu também o operário.

Cresceu em alto e profundo

Em largo e no coração

E como tudo que cresce

Ele não cresceu em vão

Pois além do que sabia

- Exercer a profissão -

O operário adquiriu

Uma nova dimensão:

A dimensão da poesia.

E um fato novo se viu

Que a todos admirava:

O que o operário dizia

Outro operário escutava. 


\section{O operário em (des)construção • Adilson Citelli}

E foi assim que o operário Do edifício em construção Que sempre dizia sim Começou a dizer não. E aprendeu a notar coisas

A que não dava atenção:

Notou que sua marmita Era o prato do patrão Que sua cerveja preta Era o uísque do patrão Que seu macacão de zuarte Era o terno do patrão Que o casebre onde morava Era a mansão do patrão Que seus dois pés andarilhos Eram as rodas do patrão Que a dureza do seu dia Era a noite do patrão Que sua imensa fadiga Era amiga do patrão.

E o operário disse: Não! E o operário fez-se forte $\mathrm{Na}$ sua resolução.

Como era de se esperar As bocas da delação Começaram a dizer coisas Aos ouvidos do patrão. Mas o patrão não queria Nenhuma preocupação - "Convençam-no" do contrário Disse ele sobre o operário $\mathrm{E}$ ao dizer isso sorria.

Dia seguinte, o operário Ao sair da construção Viu-se súbito cercado Dos homens da delação E sofreu, por destinado Sua primeira agressão. Teve seu rosto cuspido Teve seu braço quebrado 
Mas quando foi perguntado

O operário disse: Não!

Em vão sofrera o operário

Sua primeira agressão

Muitas outras se seguiram

Muitas outras seguirão.

Porém, por imprescindível

Ao edifício em construção

Seu trabalho prosseguia

E todo o seu sofrimento

Misturava-se ao cimento

Da construção que crescia.

Sentindo que a violência

Não dobraria o operário

Um dia tentou o patrão

Dobrá-lo de modo vário.

De sorte que o foi levando

Ao alto da construção

E num momento de tempo

Mostrou-lhe toda a região

E apontando-a ao operário

Fez-lhe esta declaração:

- Dar-te-ei todo esse poder

E a sua satisfação

Porque a mim me foi entregue

E dou-o a quem bem quiser.

Dou-te tempo de lazer

Dou-te tempo de mulher.

Portanto, tudo o que vês

Será teu se me adorares

E, ainda mais, se abandonares

$\mathrm{O}$ que te faz dizer não.

Disse, e fitou o operário

Que olhava e que refletia

Mas o que via o operário

$\mathrm{O}$ patrão nunca veria.

O operário via as casas

E dentro das estruturas

Via coisas, objetos

Produtos, manufaturas.

Via tudo o que fazia 


\section{O operário em (des)construção • Adilson Citelli}

O lucro do seu patrão

E em cada coisa que via

Misteriosamente havia

A marca de sua mão.

E o operário disse: Não!

- Loucura! - gritou o patrão

Não vês o que te dou eu?

- Mentira! - disse o operário

Não podes dar-me o que é meu.

E um grande silêncio fez-se

Dentro do seu coração

Um silêncio de martírios

Um silêncio de prisão.

Um silêncio povoado

De pedidos de perdão

Um silêncio apavorado

Com o medo em solidão.

Um silêncio de torturas

E gritos de maldição

Um silêncio de fraturas

A se arrastarem no chão.

E o operário ouviu a voz

De todos os seus irmãos

Os seus irmãos que morreram

Por outros que viverão.

Uma esperança sincera

Cresceu no seu coração

E dentro da tarde mansa

Agigantou-se a razão

De um homem pobre e esquecido

Razão porém que fizera

Em operário construído

O operário em construção.

\section{REFERÊNCIAS BIBLIOGRÁFICAS}

MENESES, Adélia Bezerra de. Desenho mágico: poesia e política em Chico Buarque. São Paulo: Hucitec, 1982.

SILVA, Thais Santi Cardoso. Reconstrução da liberdade moderna a partir de um diálogo entre estrutura e subjetividade. Sequência: revista do curso de 
comunicação \& educação • Ano XV • número 2 • maio/ago 2010

pós-graduação em Direito da UFSC. Florianópolis: Fundação Boiteux, n. 47, p. 33-57, dez. 2003. Disponível em: <http://www.buscalegis.ufsc.br/sequencia > Acesso em: 29 mar. 2010.

\section{Endereços eletrônicos}

Chico Buarque: vida. Disponível em: <http://www.chicobuarque.com.br/vida $>$. Acesso em: 29 mar. 2010.

"Construção". Disponível em: <http://www.chicobuarque.com.br/construcao/ mestre.asp?pg=construc_71.htm>. Acesso em: 29 mar. 2010.

"O operário em construção". Disponível em: <http:/ /www.viniciusdemoraes.com. br/poesia/index.php>. Acesso em: 29 mar. 2010.

Vinicius de Morais: biografia. Disponível em: <http://www.releituras.com/ viniciusm_bio.asp >. Acesso em: 29 mar. 2010. 